\title{
Evaluation of reproductive and animal welfare parameters of swine females of different genetic lines submitted to different reproductive management and housing systems during pregnancy
}

[Avaliação de parâmetros reprodutivos e de bem-estar animal de fêmeas suínas de diferentes linhagens genéticas submetidas a diferentes sistemas de manejo

reprodutivo e de alojamento durante a prenhez]

\section{Bampi ${ }^{1,2}$, K.K. Borstnez ${ }^{3}$, C.P. Dias ${ }^{4}$, O.A.D. Costa ${ }^{5}$, F. Moreira ${ }^{1,3}$, V. Peripolli ${ }^{1,3 *}$,} J.M. Oliveira Júnior ${ }^{3}$, E. Schwegler ${ }^{1,3}$, L.P. Rauber ${ }^{6}$, I. Bianchi ${ }^{1,3}$

\author{
${ }^{1}$ Programa de pós-graduação - Instituto Federal Catarinense - Campus Araquari - Araquari, SC \\ ${ }^{2}$ Pamplona Alimentos S/A - Rio do Sul, SC \\ ${ }^{3}$ Núcleo de Pesquisa, Ensino e Extensão em Produção Animal (NEPPA) - Instituto Federal \\ Catarinense, Campus Araquari - Araquari, SC \\ ${ }^{4}$ Universidade Estadual de Londrina - Londrina, PR \\ ${ }^{5}$ Embrapa Suínos e Aves - Concórdia, SC \\ ${ }^{6}$ Instituto Federal Catarinense Campus Concórdia - Concórdia, SC
}

\begin{abstract}
The aim of this study was to evaluate swine females of different genetic lines submitted to different reproductive management and housing systems during pregnancy on reproductive performance and animal welfare parameters. After artificial insemination protocol, 524 females were divided into two gestation housing systems: PEN1=animals housed in individual stalls during the breeding and after group-housed; PEN32=animals housed in individual stalls from breeding until 32 days of pregnancy and after group-housed. The number of piglets born, and the pregnancy and farrowing rates were evaluated. Welfare parameters related to the pregnancy phase were used. Females who weaned more piglets in the previous farrowing had a higher number of piglets born at the next farrowing. The pregnancy rate was affected by the number of semen doses. The farrowing rate was not influenced by the evaluated parameters, with average value of $91.36 \%$. There was no effect of the gestation housing system and the genetic lines on pregnancy and farrowing rates, with values above $90.0 \%$. The animal welfare indicators showed more compromised parameters in PEN1 system. PEN1 system did not impair the reproductive performance although it presented more compromised animal welfare parameters.
\end{abstract}

Keywords: group-housed, individual stalls, pregnancy phase, sow

\section{RESUMO}

O objetivo deste estudo foi avaliar fêmeas suínas de diferentes linhagens genéticas submetidas a diferentes sistemas reprodutivos de manejo e alojamento durante a prenhez sobre parâmetros de desempenho reprodutivo e bem-estar animal. Após o protocolo de inseminação artificial, 524 fêmeas foram divididas em dois sistemas de alojamento de gestação: PEN1=animais alojados em baias individuais durante o protocolo de inseminação artificial e, depois, alojados em grupo; PEN32=animais alojados em baias individuais desde o protocolo de inseminação artificial até 32 dias de prenhez e, depois, alojados em grupo. O número de leitões nascidos e as taxas de prenhez e parto foram avaliados. Parâmetros de bem-estar relacionados à fase gestacional foram utilizados. As fêmeas que desmamaram mais leitões no parto anterior tiveram um maior número de leitões nascidos no próximo parto. A taxa de prenhez foi afetada pelo número de doses de sêmen. A taxa de parto não foi influenciada pelos fatores avaliados, com valor médio de $91,36 \%$. Não houve efeito do sistema de alojamento gestacional e das linhas genéticas sobre as taxas de prenhez e parto, com valores acima de 90,0\%. Os indicadores de bem-estar animal mostraram parâmetros mais comprometidos no sistema PEN1. O sistema PEN1 não prejudicou o desempenho reprodutivo, embora tenha apresentado parâmetros de bem-estar animal mais comprometidos.

Palavras-chave: alojamento coletivo, baias individuais, fase da gestação, porca

Recebido em 30 de outubro de 2019

Aceito em 11 de março de 2020

*Autor para correspondência (corresponding author)

E-mail: vanessa.peripolli@hotmal.com 


\section{INTRODUCTION}

The European Union (EU) has been a pioneer in the development of many measures to improve animal welfare in the production system, and since 2013 it has become mandatory to abolish individual pen for sows and gilts after 28 days of pregnancy and obligated to use group-housed after this period (Knox et al., 2014; Dias et al., 2018).

As in the EU, Canadian swine producers are also in the constantly seeking to reconcile animal welfare and productivity as well as food security. For this, swine females when housed in individual stalls may remain for only 28 days after the last breed, and an additional period of up to 7 days, if necessary, to manage regrouping (Code..., 2014). In New Zealand, another country concerned with animal welfare relations and productivity, the recommendation is the removal of sows and gilts from pregnancy stall soon after breeding, with a maximum tolerance of 7 days after artificial insemination (AI) to transfer to a group-housed system (New Zealand, 2018). The current scenario of the Brazilian consumer market demands improvements regarding the housing and rearing methods of these animals (Yunes, et al., 2017).

The use of pregnancy pen has always been aimed facilitating the management and to optimize the distribution of the animals as well as to increase available space on farms, reduce hierarchical disputes and standardize supply and consumption of feed. However, swine are gregarious animals, which require constant social contact and interaction in a friendly way more often than aggressively (Fraser, 1999). According to Held and Spinka (2011), their interactive capacity is given by jokes and disputes for objects made available through environmental enrichment. However, when the animals are individually pen housed, there is a partial commitment or impairment of their communicative capacity and, consequently, of their freedom to express their natural behavior. Also, the little capacity of movement due to the restriction of space can predispose locomotor and genitourinary problems (Silva et al., 2008).

The adoption of new housing systems for sows, such as group-housed, presents a series of challenges to the pig industry and the appropriation of an animal welfare system may affect the current performance of the farms, such as the number of weaned piglets per sow per year (Spoolder et al., 2009). Horback and Parsons (2016) observed that behavioral differences were responsible for the variation of up to $60 \%$ of the data obtained, such as aggressiveness, fear of humans and active/exploratory animal when taking into account collective housing, due to the personality of each pregnant sow housed in large groups.

The group-housed system still presents contradictory results regarding pregnancy rate and litter size. Studies showed that group-housed females after AI may result in a decrease in the reproductive performance (Estienne et al., 2006; Karlen et al., 2007; Munsterhjelm et al., 2008) probably due to stressors in the embryo fixation period that occurs between the 17th and 24th pregnancy days (Alvarenga et al., 2013) that could result in embryonic and gestational losses. In spite of other factors such as genetic line and reproductive management traits i.e. parity order, lactation length in the previous parturition, number of weaned piglets in the previous farrowing, artificial insemination (AI) method and number of AI doses can influence the reproductive and animal welfare parameters of swine females. Therefore, the aim of this study was to evaluate swine females of different genetic lines submitted to different reproductive management and housing systems during pregnancy on reproductive performance and animal welfare parameters.

\section{MATERIAL AND METHODS}

Animal care procedures throughout the study followed protocols approved by the Ethics Committee for Animal Use (CEUA) at Instituto Federal Catarinense, number 180/2016. The experiment was carried out in a commercial farm, located in Pouso Redondo city $\left(27^{\circ} 15^{\prime} 29^{\prime \prime} \mathrm{S}\right.$ and $\left.49^{\circ} 56^{\prime} 02^{\prime \prime} \mathrm{W}\right)$, in Santa Catarina state. A total of 524 females (49 gilts and 475 sows) were used in the evaluation of the reproductive performance and 166 sows were used in the evaluation of the animal welfare indicator parameters.

During the pre-breeding the females were feed with lactation diet used to provide flushing, containing $87.89 \%$ of dry matter, $20.55 \%$ of crude protein, $3,400 \mathrm{kcal}$ of metabolizable energy and 
$1.15 \%$ of digestible lysine. The pregnancy diet contained $85.60 \%$ of dry matter, $15.96 \%$ of crude protein, $3,150 \mathrm{kcal}$ of metabolizable energy and $0.82 \%$ of digestible lysine. All females received the same diet with the same ingredients and storage period, offered twice a day with water provided ad libitum.

From the first day after weaning the sows were submitted to tolerance reflex to the mature boar once a day in the morning. After estrus identification the females were inseminated the first time and after an interval of $24 \mathrm{hs}$ until the end of the tolerance reflex to the boar $(1 ; 2 ; 3 ; \geq 4$ number of AI doses). Artificial insemination (AI) in gilts were performed with homospermic doses with volume of $80 \mathrm{ml}$ at the concentration of de 3.0 x $10^{9}$ spermatozoa. For sows post-cervical AI were performed using homospermic doses with volume of $45 \mathrm{ml}$ at the concentration of $1.5 \times 10^{9}$ spermatozoa.

The female distribution occurred randomly to one of the following housing systems after AI protocol: PEN1=295 females (21 gilts and 274 sows) housed in individual stalls during the breeding and after group-housed, and PEN32=229 females (28 gilts and 201 sows) housed in individual stalls from breeding until 32 days of pregnancy and after group-housed. Gilts and sows were grouped in separate groups. The females were housed in groups of 11 females per pen with a floor space allowance of approximately $1.81 \mathrm{~m}^{2}$ per female. The pen floor was partially slatted, with drinking nipple and automated drop feeders.

The body condition score ( 1 to 5 scale) and the size of the animals were the criteria used to group the 11 females in the same pen. Females were classified according to the following parameters: gestation housing system (PEN1; PEN32); parity order $(\leq 2 ; 3$ to $5 ; 6$ or more), lactation length in the previous parturition ( 0 (gilts); $\leq 21 \mathrm{~d} ; 22$ to 27 $\mathrm{d} ; \geq 28 \mathrm{~d}$ ), genetic line (Agroceres Camborough 25; F1Pamplona; Penarlan; TOPIGS TN70), number of weaned piglets in the previous farrowing (0 (gilts); 1 to $11 ; 12$ to $14 ; \geq 15)$, artificial insemination method (intracervical; post-cervical), and number of $\mathrm{AI}$ doses $(1 ; 2 ; 3$; $\geq$ 4).
On the 25th day after the AI protocol, the pregnancy rate was obtained by a real-time ultrasound examination using a transducer of 2.90Mhz (Welld Ultrasound Scanner, China). During farrowing, the number of piglets born were obtained through Agrosui ${ }^{\circledR}$ software (Agromanager Sistemas ${ }^{\circledR}$, Brazil). Removal records by locomotor problems as well as death, were kept throughout the experimental period. During the experiment period three dataloggers (Asko, Brazil) were allocated to record the temperature and humidity within pregnancy building, with records every 30 minutes. The average temperature ranged from $21.3^{\circ} \mathrm{C}$ to $23.0^{\circ} \mathrm{C}$, being the maximum temperature ranging from $36.2^{\circ} \mathrm{C}$ to $34.4^{\circ} \mathrm{C}$ and the minimum from $7.4^{\circ} \mathrm{C}$ to $19.5^{\circ} \mathrm{C}$. The average relative humidity of the air recorded ranged from $52.2 \%$ to $82.0 \%$.

To evaluate the welfare parameters the indicators of the Welfare Quality® (2009) protocol were considered and adapted, with the parameters related exclusively to the pregnancy phase (Table 1). Each indicator was scored with " 0 " attributed to the observations in which well-being was considered good or "1" well-being was compromised or severely compromised (Dias et al., 2018), except for the body condition score indicator that was only observed individually in a 1 to 5 scale. The females of both groups (PEN1 and PEN32) were visually and individually observed during 40 to 60 seconds at two different times throughout the experiment, before 35 days of pregnancy (between 7 and 20 days) and after 35 days of pregnancy (between 42 and 65 days), when all the females were group-housed. The observation of all the indicators was made in constant contact with the animal, with the hand under head, ceilings, paws and other parts according to the Welfare Quality® (2009) protocol. Females resistant to contact that remained running away were considered committed due to human presence. The same animal could have no compromised welfare parameters, one, two, three or more, regardless of the degree of commitment. 
Table 1. Parameters of welfare of swine females during gestation

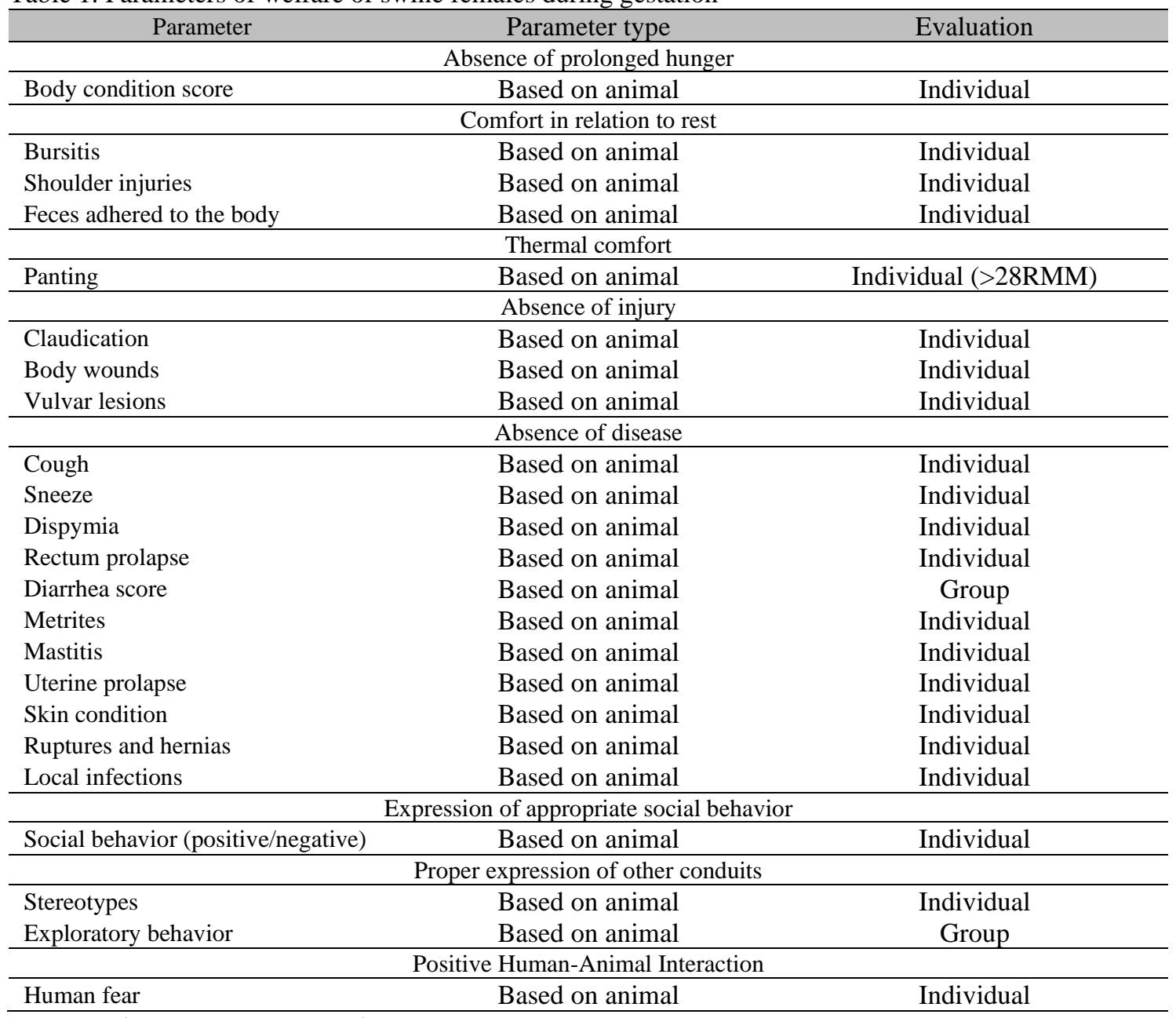

RMM: respiratory movement per minute

The data were analyzed using the Statistical Analysis System software (SAS Inst. Inc., Cary, NC, v.9.4). Each individual female was considered an experimental unit. The total number of piglets born was analyzed using the NPAR1WAY procedure and the effect of housing system, genetic line, parity order, total weaning, lactation length in the previous farrowing, insemination method and total doses of semen was compared by the Kruskal-Wallis test. The number of compromised welfare parameters was analyzed by the same procedure and the effect of housing system was compared by the KruskalWallis test.

For the variables with a binary response (pregnancy rate and farrowing rate), the analysis was performed using a binary distribution (GLIMMIX procedure). In this model housing system, genetic line, parity order, total weaning, lactation length in the previous farrowing, insemination method and total doses of semen were considered as fixed effect and the replicates as random effect. Significance was set as $\mathrm{P} \leq 0.05$ for all tests and $\mathrm{P}$ values between 0.05 and 0.1 were considered a statistical trend.

\section{RESULTS}

Females who weaned more piglets in the previous farrowing had a higher number of piglets born at the next farrowing $(\mathrm{P}=0.0012)$ (Table 2). The females housed in the PEN1 system tended to have a higher number of piglets born than the females housed in the PEN32 system $(\mathrm{P}=0.0696)$, 15.27 and 14.55 respectively. The same trend $(\mathrm{P}=0.0557)$ was also observed for the artificial insemination method, in which post-cervical 
artificial insemination method resulted in a higher number of piglets born (15.03) than the intracervical AI method (14.35).

The pregnancy rate (Table 2) was affected by the total doses of semen $(\mathrm{P}=0.0378)$. Females inseminated with three doses of semen had a higher pregnancy rate $(95.58 \%)$ than females inseminated with two $(88.99 \%)$ or one $(87.50 \%)$ dose of semen. The farrowing rate was not influenced by the evaluated factors, with average value of $91.36 \%$. The frequency of compromised welfare parameters up to 35 days of pregnancy $(\mathrm{P}=0.0085)$ and above 35 days of pregnancy $(\mathrm{P}=0.0184)$ were influenced by the housing system (Table 3). In general, the PEN32 housing system resulted in smaller numbers of compromised parameters than the PEN1 housing system.

Table 2. Effect of the gestation housing system, genetic line, parity order, total weaning, lactation length, insemination method and total doses of semen on the reproductive parameters of swine females

\begin{tabular}{|c|c|c|c|}
\hline & Number of piglets born & Pregnancy rate, $\%$ & Farrowing rate, $\%$ \\
\hline \multicolumn{4}{|c|}{ Gestation housing system } \\
\hline PEN1 & 15.27 & $92.86(273 / 294)$ & $91.50(269 / 294)$ \\
\hline PEN32 & 14.55 & $91.70(201 / 229)$ & $91.23(208 / 228)$ \\
\hline $\operatorname{Pr}>\mathrm{F}$ & 0.0696 & 0.8216 & 0.8438 \\
\hline \multicolumn{4}{|l|}{ Genetic line } \\
\hline Agroceres & 14.73 & $93.24(276 / 296)$ & $92.20(272 / 295)$ \\
\hline F1Pamplona & 14.92 & $92.86(26 / 28)$ & $92.86(26 / 28)$ \\
\hline Penarlan & 15.55 & $91.08(143 / 157)$ & $89.81(141 / 157)$ \\
\hline Topigs & 14.44 & $90.48(38 / 42)$ & $90.48(38 / 42)$ \\
\hline $\operatorname{Pr}>\mathrm{F}$ & 0.1180 & 0.5172 & 0.9105 \\
\hline \multicolumn{4}{|l|}{ Parity order } \\
\hline$\leq 2$ & 14.72 & $92.36(278 / 301)$ & $91.69(276 / 301)$ \\
\hline$\overline{3}-5$ & 15.43 & $93.82(167 / 178)$ & $92.66(164 / 177)$ \\
\hline$\geq 6$ & 14.62 & $86.36(38 / 44)$ & $84.09(37 / 44)$ \\
\hline $\operatorname{Pr}>F$ & 0.1173 & 0.4762 & 0.4844 \\
\hline \multicolumn{4}{|l|}{ Total weaning ${ }^{1}$} \\
\hline 0 (gilts) & $14.05^{\mathrm{c}}$ & $91.30(42 / 46)$ & $89.13(41 / 46)$ \\
\hline $1-11$ & $14.52^{\mathrm{bc}}$ & $94.87(185 / 195)$ & $93.33(182 / 195)$ \\
\hline $12-14$ & $15.44^{\mathrm{a}}$ & $91.60(229 / 250)$ & $90.76(226 / 249)$ \\
\hline$\geq 15$ & $15.35^{\mathrm{ab}}$ & $84.38(27 / 32)$ & $87.50(28 / 32)$ \\
\hline $\operatorname{Pr}>F$ & 0.0012 & 0.1216 & 0.0874 \\
\hline \multicolumn{4}{|l|}{ Lactation length $^{1}$} \\
\hline 0 (gilts) & 14.05 & - & $89.13(41 / 46)$ \\
\hline$\leq 21$ & 14.38 & $87.38(90 / 103)$ & $83.93(47 / 56)$ \\
\hline $22-27$ & 15.03 & $93.55(145 / 155)$ & $93.26(180 / 193)$ \\
\hline$\geq 28$ & 15.21 & $94.52(69 / 73)$ & $92.07(209 / 227)$ \\
\hline $\operatorname{Pr}>F$ & 0.0768 & 0.3728 & 0.3730 \\
\hline \multicolumn{4}{|c|}{ Insemination method } \\
\hline Intracervical & 14.35 & $90.48(57 / 63)$ & $90.48(57 / 63)$ \\
\hline Post-cervical & 15.03 & $92.56(423 / 457)$ & $91.45(417 / 456)$ \\
\hline $\operatorname{Pr}>\mathrm{F}$ & 0.0557 & 0.5593 & 0.8112 \\
\hline \multicolumn{4}{|c|}{ Total doses of semen } \\
\hline 1 & 16.42 & $87.50(7 / 8)^{b}$ & $87.50(7 / 8)$ \\
\hline 2 & 14.71 & $88.99(202 / 227)^{\mathrm{b}}$ & $88.94(201 / 226)$ \\
\hline 3 & 15.15 & $95.58(238 / 249)^{\mathrm{a}}$ & $94.38(235 / 249)$ \\
\hline$\geq 4$ & 14.79 & $92.31(36 / 39)^{\mathrm{ab}}$ & $87.18(34 / 39)$ \\
\hline$\overline{\operatorname{Pr}}>\mathrm{F}$ & 0.4832 & 0.0378 & 0.0984 \\
\hline
\end{tabular}

PEN1: females housed in individual stalls during the breeding and after group-housed; PEN32: females housed in individual stalls from breeding until 32 days of pregnancy and after group-housed; Pr $>F$ : Probability; ${ }^{\text {a-b }}$ : Values within a column with different superscripts $\operatorname{differ}(\mathrm{P}<0.05)$; ${ }^{1}$ data of the previous parturition of the female. 
Table 3. Frequency of compromised animal welfare parameters according to the gestation housing system of swine females up to and after 35 days of gestation

\begin{tabular}{ccccccc}
\hline \multirow{2}{*}{$\begin{array}{c}\text { Gestation } \\
\text { housing } \\
\text { system }\end{array}$} & 0 & 1 & 2 & 3 & Pr>F \\
\cline { 2 - 5 } & \multicolumn{7}{c}{ Committed Parameters ${ }^{1}$} & 4 & \\
\hline \multirow{2}{*}{ PEN1 } & 40.49 & 39.26 & 15.34 & 4.29 & 0.61 \\
& $(66 / 163)$ & $(64 / 163)$ & $(25 / 163)$ & $(7 / 163)$ & $(1 / 163)$ & 0.0085 \\
PEN32 & 56.45 & 37.10 & 5.65 & 0.81 & 0.00 & $(0 / 124)$ \\
& $(70 / 124)$ & $(46 / 124)$ & $(7 / 124)$ & $(1 / 124)$ & \\
PEN1 & 38.55 & 43.37 & 13.86 & 4.22 & - & 0.0184 \\
& $(64 / 166)$ & $(72 / 166)$ & $(23 / 166)$ & $(7 / 166)$ & & \\
PEN32 & 57.89 & 30.26 & 11.84 & $0.00(0 / 76)$ & - & \\
& $(44 / 76)$ & $(23 / 76)$ & $(9 / 76)$ & After 35 days of gestation & \\
\hline
\end{tabular}

PEN1: females housed in individual stalls during the breeding and after group-housed; PEN32: females housed in individual stalls from breeding until 32 days of pregnancy and after group-housed; Pr>F: Probability; ${ }^{1}$ Bursitis, Shoulder injuries, Feces adhered, Claudication, Body injuries, Vulvar lesions, Cough, Metritis, Mastitis, Skin conditions, Local infections, Social behavior, Stereotypes, Exploratory behavior and Fear of humans.

\section{DISCUSSION}

In this study we evaluated the effects of transferring females to collective pens in different moments post AI on reproductive performance and animal welfare parameters. A trend effect of the housing systems on the number of piglets born was observed, with a difference of 0.72 more piglets born in PEN1, being in agreement with results observed by Perini (2017). Although in collective pens pregnant sows can undergo diverse stress situations such as feed restriction, social conflicts, mixing fight events, and bad handling techniques, which can result in prefarrowing stress in part mediated by cortisol (Barbazanges et al., 1996), these possible stressor events seem not to have been strong enough to negatively affect the number of piglets born in the present study.

The pregnancy rate at 25 days post-breeding and the farrowing rate were above $90 \%$ in both housing systems, an index that is within the standards of the TOP50 best farms in Brazil managed by Agriness S2® (2017). This good index is a result of the movements and allocations to regroup the females occurring before the embryo implantation interval, as suggested by Alvarenga et al. (2013) and the knowledge about the establishment and maintenance of pregnancy (Spencer et al., 2004). Also, it is believed that the good relation between animal and man in the farm and the constant presence of the attentive people in the pregnancy stall may have avoided hierarchical disputes followed by prolonged fights between the females, contributing positively to the reproductive indicators.

In group-housing system, animals need a more intensive management for stimulus and diagnosis of estrus, detection of estrus return and diagnosis of pregnancy (Coleman et al., 2000). Even so, farms able to intensify assistance to sows and gilts may present favorable results (Perini, 2017). The results obtained in the study indicate that it is possible to combine welfare with the productive parameters, considering that the farrowing rate and the number of piglets born were above the Brazilian average of $91.0 \%$ and 14.50, respectively (Agriness S2®, 2017).

Females who weaned more piglets in the previous farrowing had a higher number of piglets born at the next farrowing, corroborating with the data observed by Lucia et al. (2000). Also, females who received three doses of semen in the AI protocol had a higher pregnancy rate than those who received two and one doses. This effect may be associated with the protocol used in the farm since the first IA is performed immediately after the detection of estrus, thus, females with long estrus duration will receive a higher number of doses of semen. As in swine the highest frequency of ovulation occurs in the final third of estrus (Soede and Kemp, 1997), females with long estrus received a higher number of doses of semen resulting in higher pregnancy rate. 
The frequency of compromised welfare parameters up to 35 days of pregnancy and after 35 days of pregnancy demonstrated that the housing system affected the welfare of the swine females. Less compromised welfare parameters up to 35 days of pregnancy observed in the PEN32 system may be due to the females still being in the individual stall with little movement or physical contact with the other sows, reducing the chances of injury. Less compromised welfare parameters after 35 days of pregnancy, when all females were grouped collectively, observed in the PEN32 system may be due to the females being familiarized with each other, since they stay lodged side by side with sows with similar body score and size, conditions used in the training of the animals that remained together in the same pen.

PEN1 system females were more susceptible to injuries and fights since they stayed longer in group housed situations. Usually group housed animals present higher numbers of body injury (Cunha et al. 2018), due to territorial disputes and post-breed stress that may impair in welfare indicators, however, without influencing fertility (Jansen et al., 2007). This can be justified, since the stressing factors of the regrouping have effect in the first 48 hours, stabilizing after this period (Anil et al., 2006).

Aggression among swine females in pen occurs predominantly because of competition for food or to establish social hierarchy. Generally, competition for food is short-lived, but very frequent (Maes et al., 2016). Aggression related to establishing hierarchy is less frequent, but may be more intense, so these groups require more attention. Also, factors such as large pen, dynamic groups and pen with station system feeding (SSF), predispose the aggression among females of the same group (Anil et al., 2006). The present study was carried out with static groups with a maximum of 11 females per pen, with automatic feed through drops trying to minimize aggressions among females.

In addition, the selection of less aggressive animals could be beneficial for the general productivity of the herd, since this characteristic presents high heritability (Koketsu and Lida, 2017). Therefore, the individual behavior of each female should be taken into account, since they can develop different behavioral strategies when group-housed. Thus, to streamline the investigative measures in order to facilitate these grouping forms, minimizing the aggressive individual attitudes that compromise the welfare of the females housed in stalls was very relevant (Horback and Parsons, 2016).

\section{CONCLUSION}

Group housing after breeding, genetic line, parity order and lactation length in the previous farrowing did not impair the number of piglets born, the pregnancy and the farrowing rate parameters. However, the higher frequency of compromised animal welfare parameters in group-housed after breeding females, adaptation will be inevitable in order to comply with Brazilian legislation and to seek the best quality for animals and products within the reality of the production chain.

\section{ACKNOWLEDGMENTS}

This work was supported by the National Council for Scientific and Technological Development (CNPq), Brazil. The authors are grateful to Pamplona Alimentos S/A for providing the facilities to perform this study.

\section{REFERENCES}

ALVARENGA, A.L.N.; CHIARINI-GARCIA, H.; CARDEAL, P.C. et al. Intra-uterine growth retardation affects birth weight and post natal development in pigs, impairing muscle accretion, duodenal mucosa morphology and carcass traits. Reprod. Fertil. Dev., v.25, p.387-395, 2013.

ANIL, L.; ANIL, S.S.; DEEN, J. et al. Effect of group size and structure on the welfare and performance of pregnant sows in pens with electronic sow feeders. Can. J. Vet. Res., v.70, p.128-136, 2006.

BARBAZANGES, A.; PIAZZA, P.V.; MOAL, M.L.; MACCARI, S. Maternal glucocorticoid secretion mediates long-term effects of prenatal stress. $J$. Neurosci., v.16, p.3943-3949, 1996.

CODE of practice for the care and handling of pigs. Canada: National Farm Animal Care Council, 2014.

COLEMAN, G.J.; HEMSWORTH, P.H.; HAY, M.; COX, M. Modifying stockperson attitudes and behavior towards pigs at a large commercial farm. Appl. Anim. Behav. Sci., v.66, p.11-20, 2000.

CUNHA, E.C.P.; MENEZES, T.A.; BERNARDI, M.L. et al. Reproductive performance, offspring characteristics, and injury scores according to the housing system of gestating gilts. Livest. Sci., v.210, p.59-67, 2018. 
DIAS, C.P.; SILVA, C.A.; FOPPA, L. et al. Panorama brasileiro do bem-estar de suínos. Rev. Acad. Ciênc. Anim., v.16, p.e161101, 2018.

ESTIENNE, M.J.; HARPER, A.F.; KNIGHT, J.W. Reproductive traits in gilts housed individually or in groups during the first thirty days of gestation. J. Swine Health Prod., v.14, p.241-246, 2006.

FRASER, D. Animal ethics and animal welfare science: bridging the two cultures. Appl. Anim. Behav. Sci., v.65, p.171-189, 1999.

HELD, S.D.E.; SPINKA, M. Animal play and animal welfare. Anim. Behav., v.81, p.891-899, 2011.

HORBACK, K.M.; PARSONS, T.D. Temporal stability of personality traits in group-housed gestating sows. Animal, v.10, p.1351-1359, 2016.

JANSEN, J.; KIRKWOOD, R.N.; ZANELLA, A.J.; TEMPELMAN, R.J. Influence of gestation housing on sow behavior and fertility. J. Swine Health Prod., v.15, p.132-136, 2007.

KARLEN, G.A.M.; HEMSWORTH, P.H.; GONYOU, H.W. et al. The welfare of gestating sows in conventional stalls and large groups on deep litter. Appl. Anim. Behav. Sci., v.105, p.87-101, 2007.

KOKETSU, Y.; LIDA, R. Sow housing associated with reproductive performance in breeding herds. Mol. Reprod. Dev., v.84, p.979-986, 2017.

KNOX, R.; SALAK-JOHNSON, J.; HOPGOOD, M. et $a l$. Effect of day of mixing gestating sows on measures of reproductive performance and animal welfare. $J$. Anim. Sci., v.92, p.1698-1707, 2014.

LUCIA JR. T.; DIAL, G.D.; MARSH, W.E. Lifetime reproductive performance in female pigs having distinct reasons for removal. Livest. Prod. Sci., v.63, p.213-222, 2000.

MAES, D.; PLUYM, L.; PELTONIEMI, O. Impact of group housing of pregnant sows on health. 2016. Available in: <https://porcinehealthmanagement.biomedcentral.com /track/>. Accessed in: 27 May 2018.
MUNSTERHJELM, C.A.; VALROS, A.; HEINONEN, M. et al. Housing during early pregnancy affects fertility and behavior of sows. Reprod. Domest. Anim., v.43, p.584-591, 2008.

NEW ZEALAND. Animal welfare care and procedures. Regulation $n^{\circ}$ 50, 26 March 2018.

PERINI, J.E.G.N. Comportamento, bem-estar $e$ desempenho reprodutivo de matrizes suínas gestantes alojadas em baias coletivas e em gaiolas individuais. 2017. 123f. Tese (Doutorado em Ciências Animais) Faculdade de Agronomia e Medicina Veterinária, Universidade de Brasília, Brasília, DF.

RELATÓRIO anual de desempenho da produção de suínos. Florianópolis: AGRINESS, 2017. Disponível em <http://www.asemg.com.br/site/wpcontent/uploads/2018/04/Melhores_Resultados_10Edi \% $3 \%$ A7\%C3\%A3o1.pdf> Acessado em: 10 abr. 2018.

SILVA, I.J.O.; PANDORFI, H.; PIEDADE, S.M.D.S. Influência do sistema de alojamento no comportamento e bem-estar de matrizes suínas em gestação. Rev. Bras. Zootec., v.37, p.1319-1329, 2008.

SOEDE, N.M.; KEMP, B. Expression of oestrus and timing of ovulation in pigs. J. Reprod. Fertil. Suppl., v.52, p.91-103, 1997.

SPENCER, T.E.; BURGHARDT, R.C.; JOHNSON, G.A.; BAZER, F.W. Conceptus signals for establishment and maintenance of pregnancy. Anim. Reprod. Sci., v.82-83, p.537-550, 2004.

SPOOLDER, H.A.M.; GEUDEKE, M.J.; VAN DER PEET-SCHWERING, C.M.C., SOEDE, N.M. Group housing of sows in early pregnancy: A review of success and risk factors. Livest. Sci., v.125, p.1-14, 2009.

WELFARE Quality ${ }^{\circledR}$ assessment protocol for pigs: sows and piglets, growing and finishing pigs. Netherlands:Welfare Quality® Consortium, 2009.

YUNES, M.C.; von KEYSERLINGK, M.A.G.; HÖTZEL, M.L. Brazilian citizens' opinions and attitudes about farm animal production systems. Animals. v. 7, p.1-15, 2017. 